\title{
Nursing Supervision: Studying the "Case" of the phenomenon of interorganizational articulation Nursing School and Hospital*
}

\author{
SUPERVISÃO EM ENFERMAGEM: ESTUDAR O "CASO" DO FENÓMENO DE \\ ARTICULAÇÃO INTERORGANIZACIONAL ESCOLA DE ENFERMAGEM E HOSPITAL
}

\author{
SUPERVISIÓN EN ENFERMERÍA: ESTUDIAR EL "CASO” DEL FENÓMENO DE LA \\ ARTICULACIÓN INTERORGANIZACIONAL ESCUELA DE ENFERMERÍA Y HOSPITAL
}

\section{Ana Paula Morais de Carvalho Macedo ${ }^{1}$}

\begin{abstract}
The history of this research found a suitable ethos not only by the route of the researcher, but also by the current public policies of modernization and reform that are capable of regulating and transforming the educational and health systems, as well as their professional groups. The reflection meantime developed had raised a clear perception of the organizational change processes by which they interfered with the interorganizational coordination between School of Nursing and Hospital, where internship supervision would be the main protagonist, supported by the meanings that intervening actors have assigned to them. In this context, the search for explicit epistemological and methodological choices leads to look more attentively at the problem, ascertaining it, taking into account the organizational dimensions. In this regard, the choice of a case study was related to the fact that the method allowed to answer the purpose of knowing and understanding the interorganizational coordination phenomenon between School of Nursing and Hospital, namely through the supervision of internships.
\end{abstract}

\section{DESCRIPTORS}

Clinical supervision in nursing

Organizations

Nursing schools

Teaching hospitals

Case study

\section{RESUMO}

A história desta investigação encontrou um ethos propício não só pelo percurso da investigadora, mas também pelas atuais políticas públicas de modernização e de reforma capazes de regular e transformar os sistemas educativos e de saúde, bem como os seus grupos profissionais. A reflexão entretanto desenvolvida suscitara uma perceção vincada dos processos organizacionais de mudança pelos quais estes interferiam na articulação interorganizacional Escola de Enfermagem e Hospital, onde a supervisão de estágios seria a grande protagonista, sustentada pelos significados que os atores intervenientes lhes têm atribuído. A pesquisa explícita de opções epistemológicas e metodológicas levou a olhar para o problema de uma forma mais atenta, apurando-o, tendo em conta as dimensões organizacionais. A opção por um estudo de caso prendeu-se com o facto de o método permitir responder ao propósito de conhecer e compreender o fenómeno da articulação interorganizacional Escola de Enfermagem e Hospital, concretamente através da supervisão de estágios.

\section{DESCRITORES}

Supervisão de enfermagem

Organizações

Escolas de enfermagem

Hospitais de ensino

Estudo de caso

\section{RESUMEN}

La historia de esta investigación encontró un ethos propicio no solamente por la ruta de la investigadora, pero también por las actuales políticas públicas de modernización y de reformas capaces de regular y transformar los sistemas educativos y de salud, y sus grupos profesionales. La reflexión mientras desarrollada ha suscitado una percepción incrementada, aunque algo difusa, sobre los procesos de cambio organizacionales, pelos cuales se interfería en la articulación interorganizacional Escuela de Enfermería y Hospital, y como tal, la supervisión de prácticas seria la gran protagonista sustentada pelos significados que los actores intervinientes les tienen atribuido. En este alcance, al procurarse explicitar las opciones epistemológicas y metodológicas se mira el problema de una forma más atenta, apurándolo, teniendo en cuenta las dimensiones organizacionales. En este sentido, la opción por un estudio de caso se ha prendido con el hecho de que el método permite responder al propósito de conocer y comprender el fenómeno de la articulación interorganizacional Escuela de Enfermería y Hospital, concretamente a través de la supervisión de prácticas.

\section{DESCRIPTORES}

Supervisión de enfermería Organizaciones

Escuelas de enfermería

La enseñanza de hospitales

Estudio de caso

"This work has been extracted from the doctorate dissertation entitled Nursing Internship Supervision in the Interorganizational Articulation School and Hospital,
presented to Institute for Education and Psychology (Instituto de Educação e Psicologia) of University of Minho. ' ${ }^{1}$ Ana Paula Morais de Carvalho Macedo, D. Ed.
Doctor in Education - School Organization and Administration Teacher Coordinator, Nursing Superior School of University of Minho, Campus Gualtar, Braga, Portugal. 


\section{INTRODUCTION}

We have situated this study at the historical confluence of Nursing teaching and the emergence of internship supervision, with relevance to organizational dimensions of the articulation between School of Nursing and Hospital. The methodology supporting the study of this articulation in a context of internship supervision, as far as object of empirical inquiry, is close to ethnographic research, or, in a more systematic perspective, to a naturalistic research paradigm, whose method is a case study.

The search for the conducting thread of the study, and for the criteria to be adopted so that it might accomplish its expected purpose, has been constructed during all the research process. As emphasized in "Case Study", by Robert Yin (1): "A case study is an empirical inquiry that investigates a contemporary phenomenon within its real-life context, especially when the boundaries between phenomenon and context are no clearly defined". Another major aspect pointed out by this author regards the scope of the method, comprising the logic of planning, of data collection, and of specific approaches to data analysis.

The main characteristics of case studies seem to overlap general characteristics of qualitative research: i) Case studies aim to discovery; ii) Case studies emphasize "interpretation within context"; iii) Case studies aim to represent reality in a complete and thorough manner; iv) Case studies use a variety of information sources; v) Case studies reveal vicarious experience and allow naturalistic generalizations; vi) Case studies seek to represent different and often conflicting points of view present in a social situation; vii) Case study reports use language and form more accessible than other research reports. ${ }^{(2)}$

Being so, our starting point to the choice of the "methodological paradigm" was guided by demonstrating the characteristics of the study - qualitative and descriptive, insofar we intended to emphasize mainly the logic of comprehension and discovery ${ }^{(3)}$, , rather than by theory justification and testing; such attribute led us to greater awareness of validation procedures like the representativeness of collected elements, triangulation, contrasting and comparing, highlighting the meaning of rare or exceptional cases, or weighting contradictory explanations.

The comparison between the two organizations had the following objectives: Characterize the articulation between the organization School of Nursing and the organization Hospital; Understand the explicit and implicit logics of Nursing internship supervision between the two organizations; Contribute to clarify some aspects regarding to the context of hospital work as the place of training and education for Nursing internship students; Contribute to the development of Nursing teaching in Portugal, while recognizing the importance of internship to nursing professionals' training.
Therefore, we tried to find explanations to facts related to the forms of interorganizational articulation between School of Nursing and Hospital, observing them "from inside" (4), having as a fundamental concern to capture the actors' perspectives and representations within its context - their values, beliefs, rituals and representations.

In this sense, this approach starts from actor's experiences to reconstruct the logic and particular properties of a local order, rather than the global social structure: "(...) here the priority is given to field discovery and its always particular and contingent structuration, as well to the development of descriptive and interpretative models that fit the field and its particularities and its contingencies" ${ }^{(4)}$. It was important to perceive the actors' perceptions about the interorganizational articulation between School of Nursing and Hospital, through their implicit or explicit reference to conceptions or representations of internship supervision within the context of hospital work. The most subtle way we found to study the interorganizational articulation between School of Nursing and Hospital was through the analysis of internship supervision in the hospital context, starting with some analytic dimensions we have been identifying as essential to its study and among which we highlight: hospital organization (objectives and preferences, and technology / procedures) ${ }^{(5)}$, function and control, curriculum and methods, internship supervision (supervision scenarios) and supervision strategies.

Case study, as a methodological strategy that includes a set of research methods, aims to achieve a wide comprehension of the phenomenon in its totality ${ }^{(6)}$. This idea reflected on our global concerns - to understand, as far as possible, the dynamics and organizational processes of both organizations studied. Therefore, we intended to start the empirical study with a socio-historical construction of some of the characteristics and specificities of our object of study, triangulating data from discourses and practices of internship supervision (very close to the actors) and data from documental sources, from the School of Nursing as well as from the Hospital. We passed then to another stage of the empirical study, which means passing to the case study, "an example in action" (7), studying some incidents and specific facts with selective data collection, which allowed us to capture and reflect significant elements.

The case study comprised several phases, starting with the delimitation of the field for analysis (the problematic, the initial questions and some initial explicative suppositions). The following phases were: identification of the context characteristics; construction of tools to data collection (inquiries by questionnaire and by interview, observation scripts, analysis grid for unofficial documents and minutes); field research involving direct contact of researcher with organizational reality and actors (managers, teachers, internship students and other privileged informers); data analysis and interpretation. The theoretical and conceptu- 
al framework progressively built did not result exclusively from a theoretical deduction process (arising from organizational and supervision models which support it) but also from the interaction between theoretical conceptualization and empirical research data. This means that we assume social sciences as theoretical and practical approach to social reality. There's no sense in sole theory, neither in sole practice, but only in their dialectic, though operating their distinction. This procedure meets the "process of continuous regulation of field research practice and of continuous regulation of data analysis" (8), which is fundamental to allow the researcher to build his/ her identity and to establish a series of social roles.

\section{METHOD}

According the reflections above, the field research component consisted of thematized reflection on the materials "collected" in one or another of the organizations, or simultaneously in both during the internship supervision. As all specialized literature highlights, access to field work is fundamental, as it might determinate the success or the failure of the research ${ }^{(9)}$. One of the aspects we tried to keep on our mind was the relative weight of impact in the social unit we were studying. We were deeply familiar by previous socialization or proximity ${ }^{\left({ }^{8}\right)}$. This feature became evident during all the research process. Our behavior within field work was openly and publicly assumed and we tried to keep a low profile; nevertheless, our roles were easily confused since we had a regular presence in the social context. At times, actors would recognize us as researching on that context (namely because we asked their previous authorization to do interviews, or to collect data otherwise), other times they just would forget this status and we would hold another - as supervisor, co-worker or teacher. In this sense there was a low impact; the multiplicity of roles led to a more frequent and longer permanence at the organizations School of Nursing and Hospital, so that the actors got used to our frequent presence without relating it to a distinctive role - as a researcher, as a supervisor or as a teacher.

The "crystallized" presence of the researcher in the work field, occurring after an initial integration period, "cuts both ways", and we have been aware of this during the research. If it is true that it is a major requirement for the effectiveness of observation, it is also true that it necessarily implies a local social definition, within the researcher's behavior, of what overlaps with normal daily routine and what draws attention, leading therefore to the emergence of barriers to focus on the observation field ${ }^{(8)}$. We were conscious that we had to keep a permanent focus on our object of study, which lead us to partial disruptions that generated some conflict; the final balance was positive, our personal and professional identity motivated many conversations and acted often as an approximation strategy.
The guiding questions of the study were the following: i) Does the articulation between School of Nursing and Hospital, insofar as it reveals the similarities / differences between the two organizations, favor internship supervision? ii) Does the articulation between School of Nursing and Hospital favor the integration of Nursing internship students in the context of hospital work?

At this point, we think it is essential to clarify some aspects related to the main methods of direct data collection in the field and to the specific nature of procedures, according to the theoretical references framework and to the characteristics of the object of study.

\section{Inquiry by questionnaire}

In a preliminary stage of research, we needed to recur to this data collection technique. Questionnaires were applied to the internship students of the $2^{\text {nd }}$ year of Licentiate Degree course in Nursing (three classes), corresponding to 135 internship students. This criterion was selected to befit us, since it was easy to accede to the fields of Medicine internship. This initial study had an exploratory scope, and was developed at two different times and with different objectives corresponding to the application of two questionnaires. On a first stage, we aimed to know internship students representations related to Hospital as an organization and as training place, as well as the apprenticeships they value and what they really learn - essentially relating to their initial experiences on a context of Hospital work. This exploratory approach had as objective to understand if internship students learning fitted the objectives outlined to Nursing Teaching, identifying privileged training models, or if, otherwise, students' apprenticeships could be accomplished within different training models - different of those expected for future nurses ${ }^{(10)}$. This preliminary study allowed us to systematize and deepen some aspects related to internship in Licentiate Degree course in Nursing, adding new elements to research.

\section{Inquiry by interview}

In a first phase of the study we interviewed, within both contexts, twenty three actors suitable to sample (nurses of the Hospital and teachers, most of them former students at the School), starting from a script of semi-structured questions. In this study, interview presented methodological possibilities that we have not identified in other methodologies, by recourse to narratives. In some cases, narrative turned into biographies, insofar that subjects' information assumed real sense and meaning because temporal dimension was made explicit and integrated into the problematic, which allowed us to understand the phenomenon within time course ${ }^{(11)}$.

The richness of data supplied by the actors was made possible by the utilization of autobiographical method. The nature of questions forced the actors to recur to remote memories, to previous experiences related to internship; on the one hand, their current personal condition was far 
from their past in the organizations under study, on the other hand the actors needed to remind their past as students, or even as professionals, once again motivated by the questions. When questions touched to a more or less remote past, and deviation showed as a probability through memory shortage denounced by less clear reports, we confirmed the need to recur to other techniques. In some situations it was easy to get around the progressive weakening of interviewed actors by collecting the desired information from different subjects of the interview script. Almost all teachers and nurses interviewed had a characteristic in common, since they had been students at the School. This criterion for our convenience allowed us to recur to past experiences without major constraints. Another strategy we have selected was to address to an internship supervisor (who accompanied a group of internship students) a question that did not integrate our script, but had the purpose to evaluate a precise and punctual behavior, as the example that follows: "As a teacher, how have you concretized supervision during today's internship training?"

All interviews had place outside the Hospital organization and always had into account the acceptance and availability of interviewed. The relationship of proximity with the interviewed and the comprehensive nature of interviews led us the option of recording them for posterior full transcription. Anonymity having been assured, the majority of the interviewed (with exception of three of them) accepted it without hesitating. By this we do not intend to say that we exclude the influence of contextual factors. An interview, like any face to face relationship, is always a particular social interaction, subjected to diverse readings and evaluations from part to part, which are susceptible of introducing biases in data collection ${ }^{(12)}$.

As a methodological strategy of convenience, in the next step (phase of case study or of "an example in action" (1) $)$, eight internship students from the $2^{\text {nd }}$ year of Licentiate Degree course in Nursing, five nurses and the supervisor were also interviewed, privileging two modalities of interview - semi-directive interview and directive interview.

Semi-directive interview was based on the use of a script, allowing the interviewed to express them following the flow of their own thoughts. This means that we stood on a middle ground, between two compelling and opposed requirements. On the one hand we wanted the interviewed to structure its thoughts around the envisaged object (a partially "non-directive attitude"). On the other hand, we did not want their attention to be diverted to other considerations not connected to the object, easing therefore the deepening of non-explicit aspects ${ }^{(11)}$. Being so, partially "directive" attitude was recorded on interviewer interventions. This type of interview may also be classified in a continuum: "[...] in one of its poles, interviewer favors a freer expression from his interlocutor, intervening as less as possible; in the other pole, the interviewer structures the interview from a strictly defined object of study" (11).
In what concerns to data statute, it must also be referred that there a wide possibility to obtain data, these presenting nevertheless their own limitations: "What people declare about their practices is not enough to reveal the logics that underlie to them" (11). In other words, though interviews allow an approximation to subjects' representations (whether they are opinions, aspirations or representations), they only provide data on the practices in an imperfect form.

The directive or structured interview was also applied to actors. I was based on a questionnaire with standardized questions and had a pre-established sequence. According to respective situations, interviewed were invited to: select the most appropriate answer; select a given number of answers from a set and order them according to priority sequence; answer briefly; choose scenarios within limited options. In each question with a wide set of answers we included the option "other(s)", providing a blank space for specification. At the end of the questionnaire we placed an open question; interviewed seldom filled it up and, when they did so, answers were very succinct. In this type of inquiry, the same questions were addressed to both populations; for some of the actors, particulars questions were added, relating to their statute or their function within the organization School of Nursing / Hospital.

\section{Analysis of documental corpus}

Within their framework, documents stand as "vestiges" (12) that shape the historical-educative nature of the research underlying to study. The analysis of the documents appeared therefore as adequate to this research, since it concerned a study that required the analysis of organizational features both from School of Nursing and Hospital - envisaged as social entities developing within a given context.

In this sense this research method is justified by the need to explain the reasons, as well as the legal and ethical bases, which motivated and justified practices during a significant time period.

Data collection was deduced from both contexts under study. In what concerns the School, data were collected from: Study Plans and Course Regulations; internship Pedagogical Files; meetings' minute books; Annual Assessment Reports, School newspapers; documents issued from School, of data on student population and daily school management; political-strategic documents (European regulations). In what touches to Hospital, data were collected from: Newsletters from the Hospital Board; Service Orders; Activity Reports; Plans of "In-service Training" and Training Plans from the Department of Training and Research; documents within the Accreditation Process; Norms of Professional Behavior and Criteria for Performance Assessment; Manual of Functional Contents of Professional Careers and International Norms Manual 1-55 (documents within the Accreditation Process by the King's Found Health Quality Service, started in 2011). 
The richness and relevance of data showed its potential in articulation with "privileged informants" who took part in both contexts in different times.

\section{Participant observation}

This option within field research arises from our familiarization with the social context we intended to study. The study implied a long permanence of researcher in the field and comprised the observation of a multiplicity of social reality dimensions. Therefore, it required a systematic confrontation between the perspectives of social local actors on world and society (collected through various types of verbal statements), and the data collected by direct and participant observation. This procedure allows to decode the meaning of objects and symbols, spatial configurations and rhythms, behaviors and strategies, statements and silences, acting and thinking styles; its methodological design framework points to an exhaustive work which is limited to a situation and to a time for data collection ${ }^{(13)}$.

Throughout clinical internship we recurred to this method, using an observation grid to record events judged significant to the type of study. The observation grid included two topics: i) Relationship with Organization / Care Unity; ii) Interaction with work context (spaces, times, professionals, internship students). This script included blanks for our field notes, and the records were accomplished after having been at the care unit, generally in the reunion room of another care unity where we accompanying another group of internship students.

In this sense we selected as main criteria the situation or attitude as observer, the observation process and the observation ground. We may say that, in our case, the observation was participant, systematic (regarding the "process") and verbal (regarding the "ground"). This participant observation corresponds to an observation where the observer may in some way participate in the activity of the observed, still performing, however, his/her role as observer and therefore maintaining this statute. We may say that there was an identifiable polarization, enough to keep us alert no to pass to one of the sides - going over to the other side (14). The "auscultation" of our feelings and emotions during this procedure was a significant help. We should also add that our observation addressed phenomena, tasks or specific situations where the observed actor was centered.

Although our presence as observer in such context (internship) was quite long, direct contact with observed and its selective and systematic record occurred during two weeks, for periods of one hour. Data collected in this observation allowed data crossing and comprehension, starting from inquiries by questionnaire and interview. This technique avoided the isolation of variables by not controlling or eliminating them, since it uses the technique of reduction of the observation field in accord to emerging perspectives all along the research process. It began to be descriptive, so its categories arise from experience, not from an aprioristic order. Therefore, it aims to avoid the dangers of reductionism and bias. The main inconvenient to be pointed out is the lack of generalization. However, this difficulty may be partially surpassed by the analysis of what there is in common between the diverse situations under analysis ${ }^{(13)}$.

This research method was put into practice in a Medical Unit of a Central Hospital in North Portugal Zone. At this point we must also make explicit that our option was, since the beginning, not to disclose the name of the care unit or the identification of the actors participating in the study, because we considered these would feel more comfortable to reveal their thoughts and less embarrassed when describing episodes that might give an unfavorable image of themselves. By this we mean that we respected the norms of ethics in research with human subjects - "informed consent and protection of subjects against any kind of harm" (9).

\section{Characterization of respondents}

According to the theoretical-methodological design of this research, built by phases, the actors integrating this study were successively introduced all along research course. In this sense, the sample choice was determined by their adequacy to research objectives in each one of the phases, having as a principle the diversification of respondent persons and assuring that none of the significant dimensions for the study would be forgotten. Therefore, in the $1^{\text {st }}$ and $2^{\text {nd }}$ phases we applied a questionnaire to $2^{\text {nd }}$ year internship students. In these two phases our concerns centered in the identification of situational constraints related with supervision, and on the interorganizational articulation between School of Nursing and Hospital. The question about sample and its representativeness leads us to confront two points of view that do not necessarily oppose - those of statistical technique and of sociological interpretation ${ }^{(15)}$.

The first of these techniques requires the existence of relationships to the distribution of respondents by category, while the second one requires discovery of new categories theoretically suitable. Being so, statistically weak correlations might be theoretically relevant. Statistical and theoretical relevance may not be coincident. In the $3^{\text {rd }}$ phase of this study we selected actors convenient to sample: 11 teachers (former students of the School under study); 12 nurses from the Hospital under study (former nurses directors, supervising nurses, chief nurses, nurse that integrated the Scientific and Pedagogic Commission of Training and Research Department, Assistant Nurse to Director of Nursing, Quality Coordinator Nurse, Specialist Nurse and Nurse of Reference of Medicine Service, Teaching Assistant Nurses); the actors intervening in the case study (eight students of Licentiate Degree course in Nursing, the supervisor, also a teacher at Nursing School and five nurses)
Nursing Supervision: Studying the "Case" of the phenomenon of interorganizational articulation Nursing School and Hospital Macedo APMC 
When empirical study started, the choice of the sample, "opportunity sample" ${ }^{(16)}$, was determined by its adequacy to the objectives of research, taking as a principle the diversification of respondent persons and assuring that none of the significant dimensions for the study would be forgotten. Within this reasoning, "individuals were not selected according to numerical importance of the category that they represented, but rather due to their exemplary character" ${ }^{\prime 11}$. In our case, to assure the exemplary character presupposed to assure the actors convenient to sample, those whose professional statute implied responsibility in the organization and supervision of internship, or who where implied in the very process of supervision.

\section{RESULTS}

To attain the research results it was necessary to analyze data, one of the more important and complex task of empirical research, consisting in the systematization and organization of collected materials in order to amplify its comprehension ${ }^{(15)}$. The reading of data collected in a Medicine service (through inquiry by questionnaire and interview, analysis of documental corpus and field notes) obeyed to different phases. The 1 st and 2 nd phases still corresponded to the exploratory phase whose data allowed the confirmation of a problematic. The analysis latu sensu of documental corpus and data collected trough inquiry by questionnaire allowed to identify emergent and significant units of meaning. The operations leading to an internal categorization of data a posteriori ${ }^{(17)}$ aimed to establish categories, by an inductive process, to the construction of two analysis grids in order to the reading of the observed reality. Simultaneously, other inquiries by interview were improved, assessed and validated, as well as the observation grids, to be applied in the $3^{\text {rd }}$ phase of the research project.

The $3^{\text {rd }}$ was concretized in the context of internship supervision - the Hospital. The reading of data of this last phase was accomplished with basis on two analysis grids, designed to read data in two distinct moments. One of the moments involves the transversal reading of all data which contextualized all the problematic of internship supervision, hence comprising phenomena of interorganizational articulation between a Nursing School and a Hospital, with a start on Nursing internship supervision models; the other moment engages the reading of discourses and practices of supervision in an internship context, with a start on a "Configurations of the articulation of Nursing School and Hospital". The transversal and analytical reading of the data collected by interview included, to a great measure, procedures that involved data organization, codification and categorization, and later content analysis. One of the first procedures we have taken into account was identifying with the same code the a given content in each type of interview. After having performed content analysis in each "semi-directive interview", we crossed it with the content analysis of the directive questionnaire, whose treatment al- so recurred to simple calculations which aimed to quantify some given dimensions of the object under analysis. This crossing of data collected by different ways was a significant step to help building the global sense of the representations of internship supervision, and of the interorganizational articulation School and Hospital, since treatment, analysis and interpretation required data chaining, most particularly for the comprehension of contexts underlying to perception expressed by the actors. From that moment on, we have put into proof the archetype "Configurations of the articulation of Nursing School and Hospital in Internship supervision context" ${ }^{(10)}$, from where other configurations emerged; these configurations did not result exclusively from a theoretical deduction process, but rather from an ongoing articulation between theoretical conceptualization and empirical research data, which progressively enlightened, completed and legitimated the theoretical assumptions that led to our presence in school context.

This means it was possible to explore other aspects that might even not to appear explicitly in this work but contributed to consolidate our beliefs.

In what touches specifically to intern validity, it has been in some way solved through different strategies deployed during the diverse phases, namely with recourse to triangulation at the level of multiple sources of data and methods, to participation of the actors in data interpretation, and to disclosure of researcher's presuppositions. It has clearly been an evolving, open and exploratory process, since it could be progressively enriched by progresses on the comprehension of field's particularities.

\section{CONCLUSION}

The triangulation of data about the discourses and practices in internship supervision over a significant period, very close to the actors, allowed us to obtain a picture of social, political and cultural reality of the interorganizational interaction between School of Nursing and Hospital. To a better systematization of the route of the organizations under stu$d y$, we started the analysis of their evolution, highlighting items that are essential to its comprehension.

Finally, we must mention that the designed theoretical-methodological route implied recourse to theoretical perspectives whose mobilization has later tested, making possible to reconstitute a part of research process from the data collected. We started a hermeneutical exercise with very actual data, allowing the comprehension and interpretation of the most theoretically sustained facts, having namely into account, on the one hand the clarification of nursing internship supervision and the interorganizational articulation between School of Nursing and Hospital, and on the other hand the Protocol of Articulation between School of Nursing and Hospital, according to some organizational dimensions presented in two analysis grids built to that purpose. 
This triangulated route, hereby explained, surely presents insufficiencies and omissions that result either from the confrontation between actors' discourse and practice,

\section{REFERENCES}

1. Yin R., Estudo de Caso: Planejamento e Métodos, Porto Alegre: Bookman, 2005, [ p.31]

2. Lüdke, M.; André, M. Pesquisa em Educação: Abordagens Qualitativas, São Paulo: Editora Pedagógica e Universitária, 1986. [Cf. Lüdke \& André, p. 18-20, 1986].

3. Lessard-Hébert, M.; Goyette, G.; Boutin, G. Investigação qualitativa: fundamentos e práticas. Lisboa: Instituto Piaget, 1994 [Cf. Lessard-Hébert et al., p. 95-106, 1994].

4. Friedberg, E. O Poder e a Regra. Dinâmicas da Acção Organizada. Lisboa: Instituto Piaget, 1995 [p. 301, p.300, 1995].

5. Ellström, P. "Four faces of educational organizations", Higher Education, no 12, p. 231-241, 1983.

6. Almeida, J.;. Pinto, J. A investigação em ciências sociais, Lisboa: Presença, 1990 [p. 87].

7. Dockrell, W.; Hamilton, D. Nuevas Reflexiones sobre la Investigación Educativa, Madrid: Narcea, 1983 [p. 45, 1983]

8. Costa, A. A pesquisa de terreno em sociologia. In A. S. Silva \& J. M. Pinto (orgs.) Metodologia das Ciências Sociais, Porto: Afrontamento, p. 129-148, 2003 [p. 135; 138; 2003].

9. Bogdan, R.; Biklen, S. Investigação Qualitativa em Educação. Uma Introdução à Teoria e aos Métodos. Porto: Porto Editora, 1994 [p. 115-121].

10. Macedo, A. Supervisão em Enfermagem: Construir as Interfaces entre a Escola e o Hospital. Santo Tirso: De facto Editores, 2012. or from lower researcher's ability to follow a path far from the evidences, the spontaneous, the immediate or the familiar, achieving necessary ruptures with common sense ${ }^{(18)}$.

11. Albarello, L.; Digneffe, F.; Hiernaux, J.; Maroy, C.; Ruquoy, D.; Saint-Georges, P. Práticas e Métodos de Investigação em Ciências Sociais. Lisboa: Gradiva, 1997 [p. 59-60; p. 103; p. 87; p.88, 1997].

12. Ghiglione, R.; Matalon, B. O Inquérito: Teoria e Prática. Oeiras: Celta Editora, 1992 [p. 2, 1992].

13. Estrela, A. Teoria e Prática de Observação de Classes. Uma Estratégia de Formação de Professores. Porto: Porto Editora, 1994 [p. 35, 1994]

14. Thomas, J. (1993). Doing critical Ethnography. Londre. Sage Publications. [p. 48, 1993]

15. Bogdan, R.; Biklen, S. Investigação Qualitativa em Educação. Uma Introdução à Teoria e aos Métodos, Porto: Porto Editora, 1994 [p. 75; Cf., p. 205, 1994].

16. Wragg, E. "Consulting and analysing interviews", In J. Bell, et al. (eds), Conducting Small-scale Investigations in Educational Management. London: Harper \& Row, 1984.

17. Vala, J. "A análise de conteúdo", In A. S. Silva \& J. M. Pinto (orgs.), Metodologia das Ciências Sociais. Porto: Afrontamento, p. 101-128, 2003 [Cf., p. 113, 2003].

18. Silva, A. A ruptura com o senso comum nas ciências sociais. In A. Silva and J. Pinto (orgs.), Metodologia das Ciências Sociais. Porto Afrontamento, p. 29-53, 2003. 